Webbia

Journal of Plant Taxonomy and Geography

\title{
Studies on Schismatoglottideae of Borneo LXVIII: two new species of Schismatoglottis endemic to the Danum Valley Conservation Area, Sabah, Malaysian Borneo
}

\author{
Peter C. Boyce, Sin Yeng Wong \& Kartini Saibeh
}

To cite this article: Peter C. Boyce, Sin Yeng Wong \& Kartini Saibeh (2019): Studies on Schismatoglottideae of Borneo LXVIII: two new species of Schismatoglottis endemic to the Danum Valley Conservation Area, Sabah, Malaysian Borneo, Webbia, DOI: 10.1080/00837792.2019.1639387

To link to this article: https://doi.org/10.1080/00837792.2019.1639387

Published online: 29 Jul 2019.

Submit your article to this journal $๘$

View Crossmark data $匚$ 


\title{
Studies on Schismatoglottideae of Borneo LXVIII: two new species of Schismatoglottis endemic to the Danum Valley Conservation Area, Sabah, Malaysian Borneo
}

\author{
Peter C. Boyce ${ }^{a}$, Sin Yeng Wong ${ }^{\mathrm{b}, \mathrm{c}}$ and Kartini Saibeh ${ }^{\mathrm{d}}$
}

aDepartment Biologie I, Systematische Botanik und Mykologie, Ludwig-Maximilians-Universität München, München, Germany; ${ }^{\text {bFaculty }}$ of Resource Science \& Technology, Universiti Malaysia Sarawak, Kota Samarahan, Malaysia; 'Harvard University Herbaria, Cambridge,

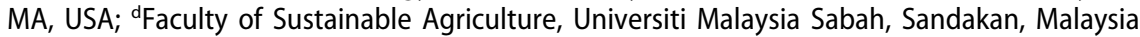

ABSTRACT

Schismatoglottis clivemarshii and Schismatoglottis priapica are described and illustrated as new species from the Danum Valley Conservation Area, Tawau, Lahad Datu, Sabah, to where both are endemic.
ARTICLE HISTORY

Received 24 May 2019

Accepted 1 July 2019

KEYWORDS

Borneo; Araceae;

Schismatoglottis; Danum

Valley Conservation Area

\section{Introduction}

Over the past 15 years the authors have undertaken fieldwork throughout much of north-west and northeast Borneo, with the majority of the first and second authors' field-based research in Sarawak, and that of the third author focusing on west Sabah (Kartini et al. 2015a), and more recently in the Tawau Hills, east Sabah (Kartini et al. 2015b; Kartini et al. 2017).

Aware that central Sabah is floristically very different from further east and from the west, and more so from Sarawak, and indeed even more poorly known, at least for the terrestrial flora, it was apparent that a preliminary survey was required in order to establish if a longer and more detailed survey was needed. Danum Valley Conservation Area was selected as a preliminary survey site as it combines ease of access of three widely different sites with a range of forest types and geology within the framework of relatively undisturbed to pristine forest habitats. This is the second paper to result from our work at Danum (see also Wong et al. 2018).

Description of the two species in this paper takes the aroid flora of Sabah to 88 described species in 21 genera (Wong and Boyce, unpublished data). This is a remarkably low total (by comparison Sarawak has 266 described species in 37 genera). Based on field observations we would expect the total number of aroid species in Sabah to easily exceed 200. Certainly, the discovery of aroid taxonomic novelties in Sabah is not exceptional (Hay and Yuzammi 2000; Hay and Herscovitch 2003; Baharuddin and Boyce 2010; Scherberich and Boyce 2013; Wong and Boyce 2013, 2014; Wong et al. 2014).

Geological occurrences in this paper are verified using Tate (2001).
Schismatoglottis clivemarshii S.Y. Wong, P.C. Boyce \& Kartini, sp. nov.

Type: MALAYSIA, Sabah, Tawau, Lahad Datu, Danum Valley Conservation Area, Tembaling Falls trail, $\quad 5^{\circ} 01^{\prime} 00.6^{\prime \prime} \mathrm{N}, \quad 117^{\circ} 44^{\prime} 40.4^{\prime \prime} \mathrm{E}, \quad 281 \mathrm{~m}$ asl, 6 July 2018, Wong Sin Yeng, P.C. Boyce \& Kartini Saibeh BORH 2703 (holotype SAN!) (Figures 1 and 2).

\section{Diagnosis}

Schismatoglottis clivemarshii is most similar to S. venusta by hapaxanthic shoots, rather coriaceous, slightly succulent leaf blades that are often variegated, a pistillate flower zone adnate to the spathe for about half its length, a staminate flower zone entirely exserted from the lower spathe chamber, thecae with the rim of the pore broken by a slit on the outer side, and by an unbroken row of staminodes along adnation of spathe and spadix. Schismatoglottis clivemarshii differs from $S$. venusta by glabrous petioles $\mathrm{D}$-shaped in cross-section and narrowly crisped-alate on the angles (vs minutely puberulent petioles terete in cross-section and lacking wings), by the presence of a well-defined naked sterile interstice (vs sterile interstice ill-defined, with the apex of the pistillate flower zone attenuate and partly naked, or sometimes with a few abortive ovaries and reduced interpistillar staminodes contiguous with the base of the staminate flower zone), by a shorter, stouter pistillate flower zone, with more laxly arranged, better-defined and larger staminate flowers, and by an appendix base wider than the top of the staminate flower zone (vs isodiametric). The two species may also be separated ecologically, with S. clivemarshii restricted to Miocene 